\title{
RAILWAY AND URBAN DEVELOPMENT IN PATRAS: TOWARDS THE IMPROVED PARTICIPATION OF LOCAL GOVERNANCE IN COMPLEX PLANNING PROBLEMS
}

\section{A B S T R R A C T}

In recent years, the topic of integrated infrastructure and urban development requires the bottom-up approach in addition to the formal planning policies. This is specifically true for complex institutional frameworks, which need the enforcement of the interested public. Due to the socio-economic crisis in Greece, infrastructure networks have already been dramatically influenced by the fragmented decision-making among the different planning levels and actors. The case study presented in the paper relates to the improvement of a railway system in Patras, Greece (in narrow terms), but, in broader terms, the case study elucidates the informal planning procedure (called Test Planning process) behind the railway improvement as such. The idea of using such a procedure in Patras emerged due to the different interests of various actors concerning the railway integration into the urban fabric in last two decades. However, it seems there is an absence of an effective cooperation between the initiators of this procedure and the local authorities. Research methodology is developed in several steps. Firstly, the broader problematic and the potential of infrastructure development will be presented. Secondly, the Test Planning process will be presented shortly. In the end, the importance of local government in such a collaborative procedure will be mentioned and the case of local actors in Patras in the different phases of the Test Planning process will be under a critical scope towards the existing situation and the benefits in future steps. 


\section{INTRODUCTION}

The development of railway infrastructure had a significant role in industrial, economical and urban growth of the cities since ever and, as such, was always the topic of strategic importance for the highest governance levels. However, since the 1970s, the need for 'consultation' and 'participation' with the 'public' emerged. The involvement of local actors concentrates on two components: firstly, they can provide 'local knowledge' about the city; secondly, they can be integrated in the development of a broader network where different stakeholders find their 'voice' and 'listen' to each other based on sufficient appreciation, trust, and communicative skills. ${ }^{1}$

Nowadays, there is a strong debate on how to integrate railway infrastructure into the spatial planning context by the decisions made not only by formal planning authorities. The case study particularly relevant for such a research is the case of Patras - a medium sized Greek city, thus with the tradition of rational model of planning and decision-making. In $19^{\text {th }}$ and early $20^{\text {th }}$ century, the city was a main trading and cultural hub and the role of the railway was remarkably decisive. Nowadays, a reliable and direct connection between Athens and Patras is a strategic project of high priority as it contributes to bridging the East-West division of high-performance transport infrastructure that exists in Greece for a longer time. However, in recent two decades, an endless discussion and unsustainable studies about a fast connection between Athens and Patras, and simultaneously the integration of the rail tracks into urban pattern, have been developed without concrete results. This stems mainly from a fragmented decision-making generated by the reluctance of the local government, OSE and ERGOSE to collaborate. ${ }^{2}$ At the same time, the city seeks for further urban development and economic growth.

Hence, the main research problem focuses on the implementation of informal planning procedures that gather various stakeholders. More precisely, it is interesting to examine the impact and the role of local government during the process of integration of railway network into the urban pattern. In other words, it is important to observe if new approaches on decision-making are developed in order to face long-term problems unsolved by traditional planning practices. In order to test aforementioned research questions, the case study of Patras or, more specifically, the Test Planning process process as, an informal planning approach, is chosen. This case study is chosen due to two reasons: 1) it deals with the complex problem of integrating the rail and urban development in Patras and its broader region, and 2) the local authorities' unwillingness to participate and collaborate with other stakeholders in such a process. 
The paper is structured as follows. After an explanation of the Test Planning process - its origin and major principles, a brief introduction to the Greek spatial planning context is given. The central part of the paper focuses on Patras case study. Firstly, the position of Patras as a hub within international, national and local context is briefly given. Then, the key stakeholders involved in Patras case study are introduced. This follows the overview of the Test Planning process in Patras, while the reaction of local government is examined in parallel. In the end, the paper concludes with the claiming the potential impact of this procedure regarding the regional and urban context with an emphasis on a strong requirement of new institutional models of decision-making.

\section{TEST PLANNING PROCESS: DEFINITION}

A Test Planning process is an informal method for achieving concrete and feasible proposals for challenging tasks in spatial planning. It stimulates a critical discourse on implementing the practical solutions regarding the longterm problems. ${ }^{3}$ Instead of traditional and formal spatial planning methods, a Test Planning process is a procedure that requires the collaboration among numerous stakeholders with different interests. More precisely, the Test Planning process gathers competitive ideas from different planning teams who work together with an interdisciplinary Steering Committee (i.e. the group of experts) on a particular spatial problem. Their results are presented, discussed, evaluated and then promoted to the Executive Committee (i.e. the group of decision-makers) for further elaboration and implementation.

\section{TEST PLANNING PROCESS: Foundation and progress}

The method of Test Planning process was developed through the so-called "Vienna Model" in the 1970s after the massive flooding of the Danube River that caused considerable damages. ${ }^{4}$ Despite the satisfactory solutions of that process, the time period of the process was needed to be shortened when this was applied to other tasks. As a result, a Test Planning process today lasts for one year, with an eventual second year as a concentration phase. The improved Test Planning process was established in 2011 by the Chair of Spatial Planning and Development, ETH Zurich. ${ }^{5}$

\section{TEST PLANNING PROCESS: The principles}

The key principles of the Test Planning process are briefly explained below: ${ }^{6}$

1. Concurrence of ideas. The core of Test Planning process is the competition of various ideas. As a result, the most efficient solution is given to the contractor against the frame of given conditions. 
2. Rhythm. Ideas and solutions become mature through the regular meetings due to a repetitive discussion and continuous testing.

3. No winner. Unlike a traditional competition, there are no unique winning proposals. This method examines the different ideas of the teams in complex tasks since, often, there is no an ideal solution.

4. Ad hoc organisation. Test Planning process is an independent procedure and the roles even of local and regional officials attribute according to this fact. As a result, alternative, impartial solutions can emerge.

5. Communication. Test Planning process related sites are about areas whose future is strongly of high public interest. Towards a public support of the results and the attraction of different actors, communicating and marketing the different steps and solutions is necessary since a very beginning of the process.

6. Problem \& solution finding. Apart from the final solutions, a redefinition or identifying new problems against the given ones take place. This turns Test Planning process to a dynamic procedure.

7. "Protected process". Ideas and solutions are firstly discussed and tested in close meetings between the teams and Steering Committee before any publication in order to develop a strong argumentation. Thus, a fruitful and discourse dialogue with different actors and the public can follow afterwards.

The main concept of the Test Planning process method relates to discussing the ideas through the planning process and highlighting the advantages and disadvantages of each proposal. Through dialogue and criticism, teams can build concrete results focusing on the existing and most important problems of the task. In general, Test Planning process provides a framework for a continuous organisation and learning while it is a flexible and open process.

Along with a fragmented and unilateral decision-making and the scarcity of strategic planning, a new methodological and customised model is required based on coordination, cooperation and communication against the conflict of interests of local government or different actors. A Test Planning process can turn to a new methodological model in order to influence the spatial practices in complicated social and spatial contexts. The constructive dialogue during the procedure is a basic element among both the teams and the interdisciplinary experts and also affects the final recommendations of Steering Committee. Thus a common ground of trust and openness is formulated among various stakeholders. $^{7}$ 
A Test Planning process ensures efficient results for complex and challenging tasks due to critical discourse. The different approaches of each team, in combination with the final recommendations of the Steering Committee, give an overall view at the real problematics and a variety of solutions to the Executive Committee. Furthermore, the substantiated arguments and results based on constructive criticism favour and support a probable second concentration phase in future. Since the most serious mistakes happen in the beginning of each planning process, the gained information from various experts and the planning teams ensure a progressive process.

\section{TEST PLANNING PROCESS in practice}

After the Vienna experience and the development of the Vienna Model, other practices were promoted as a form of collaboration between the academia and planning practice in order to create the opportunity for achieving two mutual goals - on the one hand, engaging the research for the complex planning situations, on the other, experimenting the feasibility and effectiveness of the methods and instruments developed by the so-called Action Planning school for over 30 years in different cases and different contexts. ${ }^{8}$

The case of Europa Viertel in Frankfurt am Mein (1996-today) related to the revitalisation of the shunting yard in the north-western part of the city, offered the opportunity to deal with a complex spatial problem with various actors involved. The typology of stakeholders ranges from public authorities to semiprivate companies, from players of national interest to private developers. The local authorities were one of the main interested stakeholders since the long discussion against the "aggressive" initiative of the bank started. This fact leaded to a different organisation of the process and a different management of both communication towards the public and the search for project solutions. ${ }^{9}$

Furthermore, Bovisa Gasometri's brownfield area in Milano (2006) was another case that was embedded at the daily routine of the involved Institution. In this case a municipal planning team was created instead of the control role on private planners that the municipality had until that time. ${ }^{10}$ The local authorities claimed that through a more active role in a procedure they could participate in depth regarding the city planning.

The Test Planning process was also implemented in Switzerland in the largest industrial wasteland of Solothurn area (2011/2012). Test Planning process at this case created a common ground for an efficient communication with a right timing. Moreover confidentiality and trust among both sides, local stakeholders (Canton of Solothurn, Chamber of Commerce, etc.) and the contractors were 
really decisive. On the one hand, local actors invested on a sustainable basis and came through the required strategies for future development, on the other hand, a Test Planning process ensured a safe and independent environment of planning and discussion. ${ }^{11}$

Regarding the above case studies, the role of local governance has been proofed decisive both for such an informal procedure itself and for the planning results on the focus areas. This allows enrichment and improvement of these ad hoc procedures to reach concrete results.

\section{GREEK PLANNING CONTEXT AND THE ROLE OF LOCAL GOVERNANCE}

In Greece, urban and regional planning were within the jurisdiction of the central state. The institutional transformation mainly in the 1990s enforced the decentralisation of the planning responsibilities at the regional administrations and local authorities. ${ }^{12}$ In 2011, the Kallikratis plan formed the administrative system in: seven decentralised administrations, 13 regions, 74 regional units and 325 Municipalities. Therefore, the spatial planning responsibilities are distinguished at three levels: national, regional and local.

At the national level, there are two kinds of frameworks: the "General Framework for Spatial Planning and Sustainable Development" (GFSPSD), which constitutes practically a national territorial plan and the "Special Framework for Spatial Planning and Sustainable Development" (SFSPSD), which constitutes sectorial territorial plans for the whole country provided by the Ministry of Spatial Planning and Public Works (YPEKA). The SFSPSD specifies the general guidelines, set by the GFSPSD, with regard to the following: ${ }^{13}$

- Main economic activities

- Networks and spatial distribution of technical, social and administrative services, as well as knowledge and innovation infrastructure

- Special areas (coasts, islands, mountainous and lagging zones, environmental protection areas and critical environmental, developmental and social problem zones)

At the regional level, The "Regional Framework for Spatial Planning and Sustainable Development" (RFSPSD), which constitutes practically Regional Territorial Plans, play a central role among the spatial planning instruments at the regional level. They contain the necessary guidelines concerning all factors that have a long-term impact on the development and spatial structure of the region, taking into account its placement in the international, European and national context, as well as its competitive advantages. ${ }^{14}$ 
At the local level, there are two main planning instruments: the "General Urban Plan" (GUP) and the "Town Plan Study" (TPS). The GUP covers the whole area of the municipality, providing the general guidelines for its spatial development. Local authorities are responsible for the elaboration of the GUP, while the ratification is done through the ministerial decision. This plan is reviewed after any official agreement and change. "Local Councils of Spatial Planning" is entrusted with the public participation procedure. All the above plans are approved by YPEKA. ${ }^{15}$ The public, instead of the elections, does not have a direct involvement in city planning and decision-making.

The planning of railway line that connects Athens to Patras is concerned with all the above plans. The final decision about the implementation and the alignment is taken by YPEKA in agreement with regional and local actors. On the one hand, any opposition from the municipality does not intervene practically the decision-making regarding infrastructure policies, but, on the other hand, the collaboration and agreement between the three levels of governance is required towards an integrated spatial and urban planning. Furthermore, local authorities are responsible for local issues within their administrative border. Such an issue is the waterfront of Patras that is under discussion regarding its future redevelopment for more than twenty years. The current mayor insists that a ground level railway solution would have a negative impact on the coastline creating a clear border between the city and the waterfront area. As a result, a wide field of conflicts appear producing a problematics at both the regional and local level.
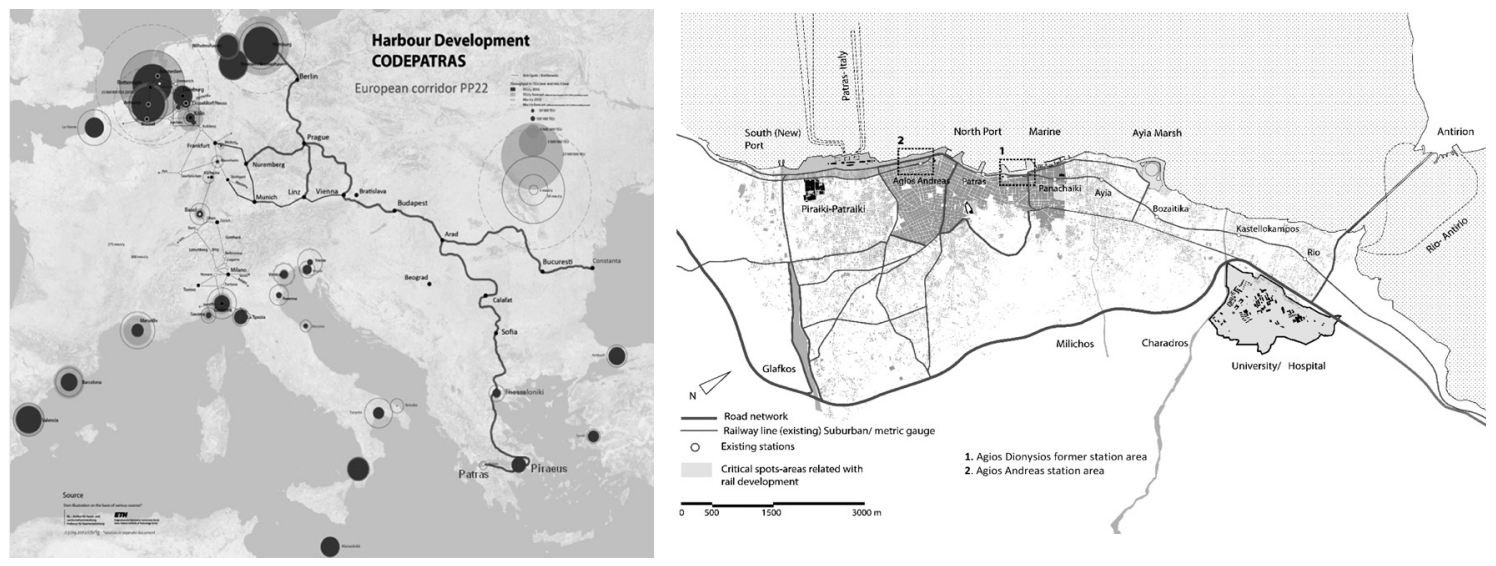


\section{TEST PLANNING PROCESS AND THE CASE OF PATRAS}

\section{PATRAS as a potential hub}

Patras case illustrates a high potential for a further transport infrastructure development, especially that of rail. It is rather important to remark that since the modern establishment of the city, both its economic and cultural profile have been closely related to its transportation importance, being largely oriented to European destinations. The specific role of the city within international, national and regional, as well as local level is presented below.

Internationa 7 7eve 7. Greece is being situated at the crossroads of three continents and the intersection of Asian and European trade routes. It is at the same time a south-eastern European gate for Asia and Africa as well as a gate to the Middle East for Europe. In addition to this, the country is currently in the middle of a geopolitical transformation due to the shifting of the global trade routes to Asia. ${ }^{16}$ Thus, Greece from a peripheral position is transferred to the heart of the Trans-European transportation networks and creates the potentials for economic development. Meanwhile, the European Commission is interested in developing a unified cross-border traffic management system including roads and railways for both transport and traffic management. ${ }^{17}$ In a more global context, Patras may be described as a part of a major worldwide economic and political 'puzzle' that has to be resolved as soon as possible (Figure 1). In an explicit way, this international character that could be directed forward, towards the expected future of Patras, seems analogous in many ways to the character of its historical neoclassical past of the $19^{\text {th }}$ and early $20^{\text {th }}$ century. ${ }^{18}$

National and regional leve7. Considering the national transport networks, Patras, as one of the most important urban centers and portal zones, is a part of the main transport corridors in Greece, such as PATHE (a road corridor connecting Patras-Athens-Thessaloniki-Euzonoi). Simultaneously with the development of the road, the air and maritime transport, the railway network will complete a future integrated transportation system both on national and regional level. In addition to this, Patras is a part of Peloponnese region that is characterized by a unique natural and cultural landscape as well as a significant primary production. Both the present and the future potential contribution of the region in Greek economy are remarkable. ${ }^{19}$ It is within this general context that the particular importance of the city of Patras has to be evaluated; not as an isolated urban territory 'enclosed' in the interior of contemporary Greek economic reality, but more likely as a part of an extended international, national and regional network of transportation relations. ${ }^{20}$ 
Loca 7 Teve 7. There are numerous hidden potentials related to the natural landscape, the historical and cultural context as well as the existing transport facilities. Firstly, Patras is shaped as an urban stripe along the coastal front and is bounded by Panachaikon Mountain in the east. ${ }^{21}$ Secondly, the history of the city and the cultural background has left an obvious imprint through important architectural spots and elements or the ancient remains. ${ }^{22}$ Finally, concerning the existing transport infrastructure, three important systems are identified: the public transportation system (intercity and local bus, the suburban railway), the port system (domestic and international ship routes to Italy and Ionian Islands) and the road system (the new by-pass and mini by-pass road) that intend to decrease the inner traffic (Figure 2). However, the above systems do not respond to an integrated strategic approach for the city.

\section{Organisation of the Test Planning process in PATRAS}

Regarding the organisation of the Test Planning process, people from interdisciplinary fields are grouped together according to the following team structure (Figure 3):

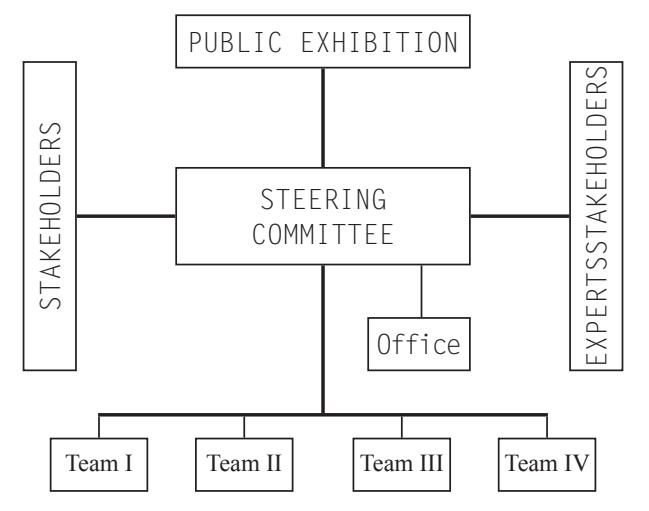

Figure 3. The organisation of the Test Planning process in Patras.

Commissioner. Commissioner is the main responsible for such a procedure and usually funds the project. In the current case, the project was commissioned by ETH Zurich under the Chair of Spatial Planning and Development.

Stakeholders instead of an Executive Committee. Usually, Executive Committee consists of two to nine persons, representatives of the decision-making authorities of the contracting political authorities and companies. It is regularly informed by the work of Steering Committee and approves the recommendations resulting from the Test Planning process. ${ }^{23}$ 
The immediate related actors of the rail operation and integration are OSE, ERGOSE, the Municipality of Patras, the Ministry of Transportation and Networks and OLPA. ${ }^{24}$ However, in the case of Patras, the Executive Committee did not exist even though its role in the process is crucial. The different interests prevent the representatives from a common discourse. This non-collaboration spirit and the negative competition is one of the main reasons that the rail integration in Patras is a long-term problem counting almost two decades of negotiations and insufficient solutions. As a result, instead of the Executive Committee, other stakeholders like OSE and the Municipality of Patras participated occasionally in the beginning of the process. The publication of the results and further communication is a common effort to reunite the various interests as a subsequent step.

Steering Committee. It often consists of seven to eleven interdisciplinary experts chosen by the commissioner as well as independent experts. ${ }^{25}$ It leads the Test Planning process, examines carefully the content and is responsible for the final recommendations and the attention of the Executive Committee. In this case, academics from ETH, the University of Patras and the University of Athens as well as international and local experts from planning, architecture and transportation fields composed the team.

Teams. In the current project, four teams participated. The different background and experiences of each team offered various insights on the task of both macro-scale and in-depth studies. Moreover, they strengthened their knowledge with more experts on economics, transport and landscape architecture. The number of the teams is wisely selected, as with a smaller number of teams there is a danger that a weak team stays out of discussion and only the contributions of two teams are included. The following four teams participated in the process:

- ASTOC, Architects \& Planners, Germany

- Feddersen \& Klostermann, Switzerland

- iocarydi.com, Greece

- International University Team (ETH Zurich, University of Patras, University of Athens)

Planning team. The team consists usually of three to four people, responsible for the preparation and the fundamentals of the Test Planning process, pretesting the project and taking the operative leadership of the process. The preparation of the task mission lasted approximately six months. ${ }^{26}$ Further meetings and workshops were supported by the Chair of Spatial Development in Zurich in collaboration with the University of Patras and the University of Athens. In the Test Planning process, a timeconsuming coordination with high level positions is avoided. 


\section{An overview of the Test Planning process in PATRAS}

In general, a Test Planning process follows different stages. In addition to the one-year period of the procedure, several steps precede and continue, inextricably being linked with the Test Planning process. Namely, preliminary steps, the test-process' phases, as well as the steps to follow the process itself are briefly explained in the following sections (Figure 4).
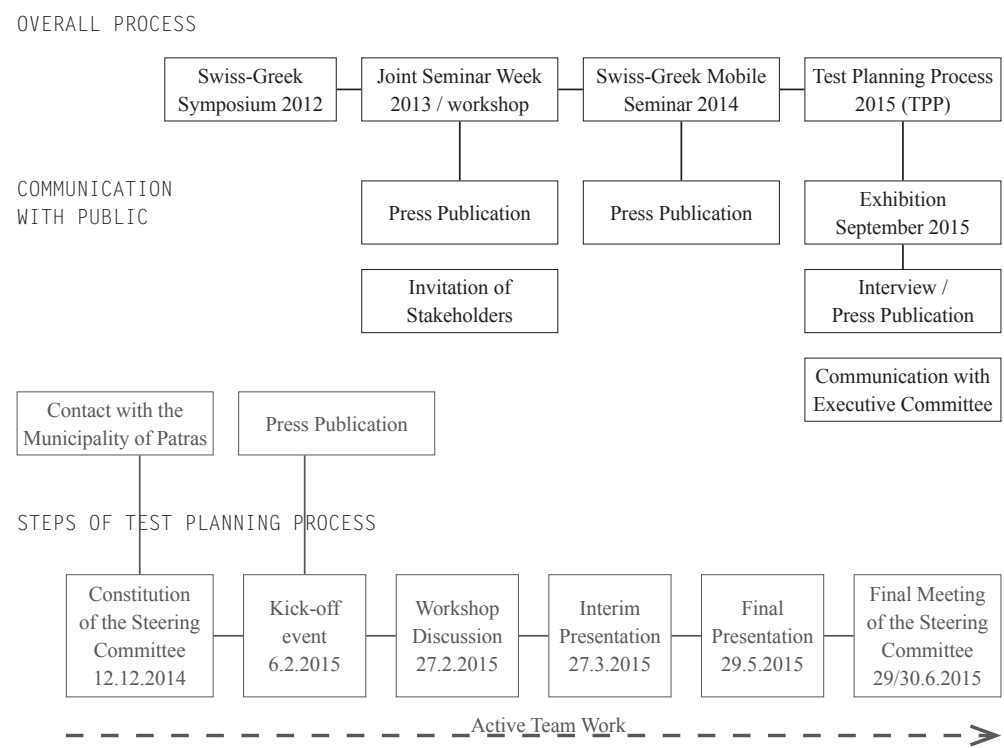

Figure 4. Test Planning process - overview of phases 2012-2015.

(Source: Frezadou, Papamichail and Signer (eds.), Rail and the City, Test Planning process for Patras)

Preliminary steps

Three main preliminary steps were undertaken before the official start of the

Test Planning process:

- In 2012 in Zurich, the Preparatory Meeting took place where the first problematics and the relevant information were presented regarding the railway and spatial development of Greece and the region of Patras. Experts with a different background from the academic and professional field participated providing their experiences on international and local level. A first idea regarding the task definition started to emerge (Figure 5).

- Later on, a Joint Seminar Week followed in the city of Patras in June 2013 between ETH Zurich, the University of Patras and the National Technical University of Athens with 35 participants. Swiss and Greek students worked in mixed groups coordinated by interdisciplinary experts. The future railway corridor between Kiato and Patras and the integration of the rail line to the urban grid was taken as a case study. The results were promising 
- alternative ideas that could be implemented gradually with manageable costs were proposed (Figure 6).

- In February 2014, a Swiss-Greek Mobile Seminar was held in Switzerland. This seminar offered the opportunity to discuss all the relevant tasks regarding an integrated infrastructure and urban approach in Patras. Through travelling at the eastern part of Switzerland the participants faced different examples of rail development. Two visits were carried out: one in Chur, at the node of the normal width track with the Rhaetian Railway and the other in Domat Ems at the industrial mixed gauge track. In Ardez/Lower Engadine, a possible Test Planning process for Patras was discussed. The former Mayor of Patras has participated in this Seminar (Figure 7).

\section{Test Planning process (TPP)}

This phase lasted 6 months including the following stages:

- 12.12.2014: Constitution of the Steering Committee. First discussion and improvement of the task mission.

- 6.2.2015: The kick-off event took place in Patras where the task was presented and the teams together with the Steering Committee and experts visited the most critical spots along the existing railway line.

- 27.2.2015: A workshop discussion took place between the Steering Committee and each team separately. The idea of the enclosed meetings was that each meeting had to keep its own direction in order to achieve various final solutions in the end, even with some common points.

- 27.3.2015: A common interim presentation was held whereas the Steering Committee as well as the members of the teams had the chance to discuss each solution and highlight the main points.

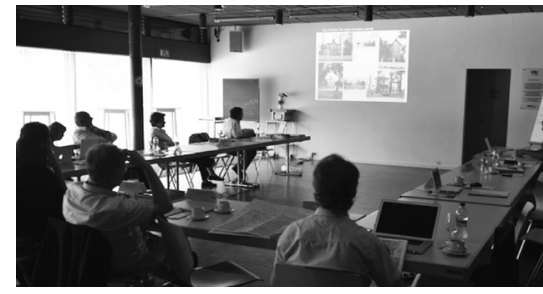

Figure 5. Swiss-Greek symposium, Zurich, 2012. (Source: Vassilis Pappas)

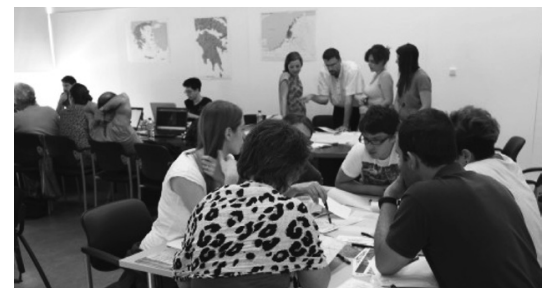

Figure 6. Joint seminar week, Patras, 2013. (Source: Vassilis Pappas)

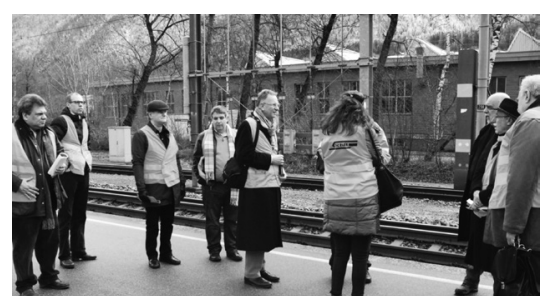

Figure 7. Swiss-Greek mobile seminar, Switzerland, 2014. (Source: Vassilis Pappas)

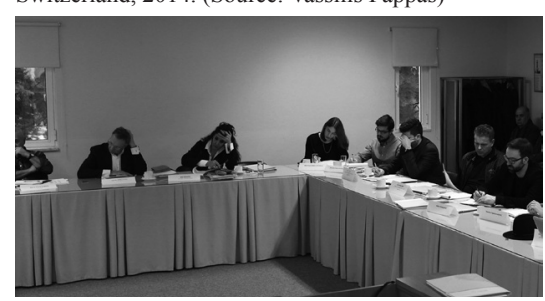

Figure 8. Test-planning process, Patras, 2015. (Source: Vassilis Pappas) 
- 29.5.2015: The final presentation took place with remarkable results. Each team presented its complete proposal and a constructive criticism followed.

- 5.6.2015: The final reports and the posters were submitted. The Steering Committee compiled them in the form of an overview for a comprehensive presentation. It should be highlighted hereby that the purpose is not to select one of the four solutions, but combine them in the most appropriate way. For this reason the final session of the Steering Committee aims to develop further recommendations to gain the attention of the Executive Committee (Figure 8).

- 29/30.6.2015: The Steering Committee met and discussed on the final proposals of the teams and on the follow-up recommendations. Afterwards, these would be transferred to the Executive Committee for further discussion and implementation.

During the above six-month procedure, the role of the Steering Committee was determinant since they were providing the correspondent feedback after each meeting and supporting any idea and solution.

Simultaneous and following steps

The communication with the public is a crucial procedure for motivating and communicating the results to all target groups since the beginning of the process. Apart from related articles in the local press and online information during the procedure, an exhibition that takes place in November 2015 will present officially the final results. Such an effort will exert to attract more actors and citizens, especially the interest of the Executive Committee, whose position until the final results remained neutral. In the current case, the Test Planning process, after its completion, will provide a foundation firstly regarding the value of a constructive dialogue and the meeting of the stakeholders who already have submitted contradictory proposals based on different interests, such as OSE, ERGOSE and the Municipality of Patras. Additionally, as a future perspective, an interactive interface is about to be established among other interested and significant stakeholder groups (citizens, NGOs, technical chambers and associations, environmentalists, etc.) regarding the implementation of the Test Planning process' results. This can be achieved through the workshops that would bring the above mentioned groups on a common ground. Regarding the socioeconomic crisis, new models of action planning should emerge. Thus, the Test Planning process as an example of merging bottom-up and top-down approaches can activate alternative procedures minimising any risks and delays. 


\section{"TRENOPHOBIA":}

\section{A social and institutional interpretation}

Beyond the spatial problems, the city of Patras faces strong social and institutional challenges. The term "trenophobia" (etym. in Greek: treno/

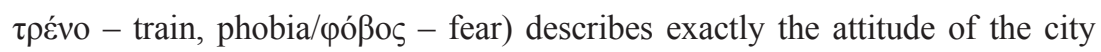
of Patras. This fear has been built by the recent economic crisis, bureaucracy, complicating political decisions and the depreciation of the commons and the lack of knowledge. More specifically, in the case of Patras, the strong opposition of the municipality is related with the waterfront redevelopment of the city. Since the rail runs along the coastline of the city, the current Mayor insists on an underground solution of 700 Mio E, already proofed inefficient. The claim that a ground level solution will destroy the waterfront area is a widespread notion ignoring international examples of such a solution. A new railway culture is absolutely urgent.

The entire Test Planning process was stimulated by the idea of creating a new railway culture, thus reversing the "trenophobia" or "railway phobia" that characterises the current attitude in Greece. Thus, the Steering Committee emphasises the fact that underground and bypass solutions do not add extra value to a city. In fact, it is usually the opposite, they create more costs, and at the same time, they separate the city from the railway network. Therefore, this Test Planning process focused on city-level solutions for a railway service that will not only be functional but also offer a new city identity. ${ }^{27}$ More specifically, the relative low-cost ground level solution compared with the underground one provides more advantages, such as a low-cost investment on the railway and more funding for the redevelopment of the waterfront.

\section{CONCLUDING REMARKS}

Greek social and institutional context lacks collaboration and communication in the process of spatial and urban planning. The deepest fear of the railway revitalisation and its integration into the urban pattern is seen on both the social and institutional level. Personal interests, mistrust and fake promises have entrapped the collective notion. Past announcements and activities, which turned to a continuous propaganda and prejudices in political life, have extremely delayed both the railway system improvement and the urban development for more than twenty years. 
Collaborative procedures such as the Test Planning process and the essential participation of local government can change the way of decision-making. The potential of such an approach concentrates on more fast and concrete results on spatial and infrastructural development, especially in a very critical period for Greece. Moreover, the real problems and needs of the city beyond any political and local interests are detected and put through a fruitful dialogue during a reasonable time. In addition to this, the proper rhythm of the procedure reveals the real problematic while it produces "seams" between fragmented decisions and actions regarding complex spatial and urban planning issues.

Underpinning these developing ideas about a new procedure in planning, thus reflected on social and institutional context, we can consider new planning approaches as active processes different form the traditional top-down strategies in the past. However, top-down planning is not excluded in the Test Planning process, but is complemented with the bottom-up approaches. In addition to this, the above described procedure provides the basis for a more intense social interaction where local governance and the citizens can face each other in a common arena. And sometimes these conflicts are necessary - they can turn to a positive outcome beyond any fears and propaganda that is generated by the concentration of the power and lack of knowledge. 
See: Panagiotis Getimis and Georgia Giannakourou, "The evolution of Spatial Planning in Greece after the 1990s: Drivers, directions and agents of change," in Spatial Planning Systems and Practices in Europe, eds. Mario Reimer, Panagiotis Getimis and Hans Blotevogel (New York: Routledge, 2014); Bernd Scholl, Konstantinos Moraitis and Vassilis Pappas, CODE ATHENS: Railway and the City Development in Athens (fortcoming). system in the European context, accessed January 27, 2015, http:courses.arch.ntua.gr/fsr/129888/ Serraos_Gianniris Zifou-1.pdf.

For instance, this is greatly illustrated in the hub deal between Hewlett-Packard, Cosco and TrainOSE, increasing the geopolitical importance of the Piraeus port, thus strengthening its position among the top European ports.

TEN-T corridor Orient/east-Med is one of the most strategic European Commission's projects, since it connects the central Europe to the maritime interfaces to the North, Black, Baltic and Mediterranean seas. Irini Frezadou, Theodora Papamichail and Rolf Signer, eds. Rail and the City, Test-planning Process for Patras. (Zurich: vdf Verlag, 2015).

19 Regarding the existing Spatial Planning Framework at the regional level, an integrated transportation system in Peloponnese should be strengthened. Since there are also small-scale airports, bus connections and ports (most of them orientated as cruise ship ports), the reactivation of the existing rail network could be decisive, for tourism as well as promoting the local agricultural and art craft activities. See: Greek Official Gazette (GG), Spatial Planning Framework on Regional Level (Art. 25294-FEK, 1485/10-10/2003) (Athens: National Printing Office, 2003). Frezadou, Papamichail and Signer, eds. Rail and the City.

21 Moreover, a water axis perpendicular to the existing rail tracks as well as open and green spaces can be included to a general strategic plan and be correlated in an extended and peri-urban green network. In addition to this, Patras is significant educational and research center due to the University, the Technical Institute, the Science Park etc. concentrating ca. 30000 students and scientific staff. Scholl, Staub and Vinzens, Test Planning. OLPA, Organization of Patras Port. Scholl, Staub and Vinzens, Test Planning. Ibid.

Frezadou, Papamichail and Signer, eds. Rail and the City. Process for Patras. Zurich: vdf Verlag, 2015.

Getimis, Panagiotis, and Georgia Giannakourou. "The evolution of Spatial Planning in Greece after the 1990s: Drivers, directions and agents of change." In Spatial Planning Systems and Practices in Europe, edited by Mario Reimer, Panagiotis Getimis, and Hans Blotevogel. New York: Routledge, 2014.

Greek Official Gazette (GG). Spatial Planning Framework on Regional Level (Art.25294-FEK 1485/10-10/2003). Athens: National Printing Office.

Healey, Patsy. "Building institutional capacity through collaborative approaches to urban planning." Environment and Planning A 30 (1998): 1531-1546.

Scholl, Bernd, Bernard Staub, and Michael Vinzens, eds. Test Planning - A Method with a Future. Zurich: vdf Verlag, 2013.

Scholl, Bernd, Konstantinos Moraitis, and Vassilis Pappas. CODE ATHENS: Railway and the City Development in Athens (fortcoming).

Serraos, Konstantinos, Elias Gianniris, and Maria Zifou, The Greek spatial and urban planning system in the European context, accessed January 27, 2015, http:courses.arch.ntua.gr/fsr/129888/ Serraos_Gianniris_Zifou-1.pdf.

Tosoni, Ilaria. "Shared Spatial Strategies and Action Design". PhD diss., ETH Zurich, 2014. 


\section{STRATEGIJA INTEGRALNOG URBANOG RAZVOJA KAO INSTRUMENT UPRAVLJANJA URBANIM RAZVOJEM \\ Ratka Čolić}

U radu je fokus na izazove institucionalizacije novog instrumenta planiranja - Strategije integralnog urbanog razvoja (SIUR). Započinje sa diskusijom o podsticanju novina u upravljanju urbanim razvojem, uticaju evropskih politika urbanog razvoja i primeni novog planskog instrumenta. Podsticano zahtevima za efektivnijim i fleksibilnijim planiranjem, upravljanje urbanim razvojem je uticalo na primenu različitih instrumenata u praksi. Jedan od njih je i strategija integralnog urbanog razvoja. Procesi izrade strategija u tri srpska grada predstavljaju prva iskustva operacionalizacije kolaborativnog pristupa i integralnog strateškog planiranja urbanog razvoja u Srbiji kao postsocijalističkom kontekstu, koji se prilagodjava tržišno orijentisanom modelu planiranja. Kao takav, poseduje endogeni karakter i značenje u okviru lokalne prakse planiranja. Kao ključni izazovi primene strategije izdvojeni su razumevanje očekivanih ishoda njene primene i postojanje potencijala za promene. U domenu pokazatelja institucionalizacije novog instrumenta lokalni urbanisti su ukazali na značaj obezbeđivanja dalje tehničke podrške, prve iskorake u implementaciji strategija, dalje razvijanje kapaciteta i uvođenje bolje komunikacije i uspostavljanje relacija. Kao novi upravljački i planski instrument strategija je postala predmet analize u sferi uprave, struke i akademske zajednice.

KLJUČNE REČI: UPRAVLJANJE URBANIM RAZVOJEM, STRATEGIJA INTEGRALNOG URBANOG RAZVOJA, PRVA ISKUSTVA U PRIMENI KOLABORATIVNOG PLANIRANJA URBANOG RAZVOJA, IZAZOVI IMPLEMENTACIJE

\section{PROSTORNI I SAOBRAĆAJNI RAZVOJ DUŽ EVROPSKIH KORIDORA: JAČANJE KAPACITETA LOKALNIH AKTERA \\ U TRANSNACIONALNOJ SARADNJI}

\section{Pablo Accebillo}

Integrisani prostorni i saobraćajni razvoj koridora je jedna od strategija kojom se utiče na trgovinu, ekonomski i demografski učinak u linearnim sistemima širom sveta. Međutim, takav razvoj se može razraditi na različitim nivoima: od istraživanja dinamike transnacionalne saradnje, preko analiziranja stepena integracije između prostornih i saobraćajnih politika u državama duž koridora, do fokusiranja na ulogu lokalnih aktera u nadnacionalnim pitanjima. Pošto ovaj rad predstavlja prvu fazu evropskog projekta transnacionalne saradnje u oblasti integrisanog prostornog i saobraćajnog razvoja duž Hamburg-Atina koridora u okviru programa infrastrukture iniciranog od strane Evropske Komisije, rad ima za cilj da pruži naučno zasnovan pregled najznačajnijih aspekata pomenutog koridora. Karakter rada je uglavnom opisni i shodno tome rasvetljava istraživanja u toku koja se sprovode kroz pomenuti projekat. U tu svrhu se koristi multi-skalarna perspektiva (tj. globalna, regionalna, lokalna) za analizu pojedinih indikatora vezanih za trgovinu, privredu i demografiju. Veruje se da takav temeljan prikaz obezbeđuje bolji pregled trenutne situacije. U završnom delu rada ukratko su date opšte preporuke za jačanje uloge lokalnih vlasti u složenom procesu transnacionalne saradnje.

KLJUČNE REČI: TRANSNACIONALNOST, TRGOVINA, EKONOMIJA, DEMOGRAFIJA, TRANSPORT, PROSTORNI

RAZVOJ, SARADNJA HAMBURG-ATINA KORIDOR

\section{RAZVOJ ŽELEZNICE I URBANI RAZVOJ U PATRASU: \\ KA UNAPREĐENJU UČEŠĆA LOKALNE SAMOUPRAVE U KOMPLEKSNIM PROBLEMIMA PLANIRANJA}

\section{Theodora Papamichail}

U poslednjih nekoliko godina, tema integrisane infrastrukture i urbanog razvoja, pored formalnih politika planiranja, promoviše pristup odozdo-na-gore. Ovo se posebno odnosi na kompleksne institucionalne okvire koje je potrebno osnažiti učešćem zainteresovane javnosti. Zbog društveno- 
ekonomske krize u Grčkoj, na infrastrukturne mreže je dramatično uticalo fragmentisano odlučivanje između različitih nivoa planiranja i aktera. Studija slučaja predstavljena u radu, u užem smislu, se odnosi na poboljšanje železničkog sistema u Patrasu, u Grčkoj, a u širem smislu, studija slučaja razjašnjava neformalnu proceduru planiranja (tzv. test-planiranje) poboljšanja železničkog saobraćaja. Ideja primene takvog postupka u Patrasu se pojavila pre dve decenije kao rezultat iskazanih interesa različitih aktera vezanih za integraciju železničkog saobraćaja u urbano tkivo. Međutim, i dalje je evidentno odsustvo efikasne saradnje između inicijatora ovog postupka i lokalnih vlasti. Metodologija istraživanja u radu je razvijena u nekoliko koraka. Prvo, biće predstavljen širi problem i potencijal razvoja infrastrukture. Drugo, ukratko će biti predstavljen proces test-planiranja. Na kraju, biće pomenut značaj lokalne samouprave u takvom postupku saradnje i slučaj lokalnih aktera u Patrasu u različitim fazama procesa test-planiranja, kao kritički okvir postojećeg stanja i pouka za buduće korake.

KLJUČNE REČI: ŽELEZNIČKA INFRASTRUKTURA, URBANI RAZVOJ, SARADNJA, NEFORMALNE PROCEDURE ZA PLANIRANJE, GRČKA

LOKALNE RAZVOJNE STRATEGIJE BEZ STRATEŠKOG RAZMIŠLJANJA:

IZGUBLJENE IZMEĐU IGRE POLITIČARA, RIGIDNOSTI UPRAVE I

DEPRESIJE PLANERA

\section{Danijela Milovanović Rodić}

U poslednjoj deceniji u Srbiji je izrađen veliki broj strategija različitog karaktera na centralnom, regionalnom i lokalnom nivou. Istraživanja njihovog kvaliteta pokazuju da veliki broj strateških dokumenata svojom formom zadovoljava standarde, ali da su po pitanju sadržaja bez jasne strategije i strateških projekata, da se preklapaju i da su slabo međusobno koordinisane.

U radu su identifikovane i diskutovane faze i koraci u procesu strateškog planiranja od ključnog značaja za formulisanje strateških i na dug rok održivih rešenja za razvoj određene teritorije i unapređenje života njenih građana. Osnovna teza je da u lokalnim strategijama razvoja nedostaje strateško razmišljanje, odnosno da rešenja nisu bazirana na njegovim produktima. Stavovi o uzocima odsustva strateškog u strategijama su ilustrovani konkretnim primerom - procesom izrade i sadržajem Strategije razvoja Grada Pančeva.

KLJUČNE REČI: STRATEŠKO PLANIRANJE, STRATEŠKO MIŠLJENJE, KOLABORATIVNO PLANIRANJE, PROCES PLANIRANJA

\section{TERITORIJALNA ORGANIZACIJA REPUBLIKE SRBIJE - MOGUĆNOSTI ZA REFORME \\ Bogoljub Milosavljević, Jelena Jerinić}

Trenutna teritorijalna organizacija Srbije praktično je postavljena tokom šezdesetih godina 20. veka. Velike demografske i ekonomske promene nisu se odrazile na promene u propisima o teritorijalnoj organizaciji. Takva teritorijalna organizacija osnova je jednostepenog i gotovo potpuno monotipskog sistema lokalne samouprave. Pošto daju detaljan prikaz propisa o teritorijalnoj organizaciji i lokalnoj samoupravi u prethodna dva veka, autori analiziraju sadašnji sistem i skiciraju moguće pravce reforme teritorijalne organizacije. Te predloge treba posmatrati u svetlu napora ka većoj decentralizaciji i uspostavljanju višestepene i/ili politipske lokalne samouprave.

KLJUČNE REČI: TERITORIJALNA ORGANIZACIJA, LOKALNA SAMOUPRAVA, OPŠTINE, GRADOVI, DECENTRALIZACIJA 